\title{
ON THE HISTORICAL BACKGROUND OF HABITIVE AND IZAFET CONSTRUCTIONS IN HUNGARIAN*
}

\author{
LÁSZLÓ HONTI \\ Dipartimento di Glottologia e Filologia Classica \\ Università degli Studi di Udine \\ Via Mazzini 3 \\ I-33100 Udine \\ Italia \\ litnoh@uniud.it
}

\begin{abstract}
This paper deals with two ways of expressing possessive relationships, their morphological make-up and the possible circumstances of their emergence. One of these is the habitive construction (' $\mathrm{X}$ has $\mathrm{Y}$ '), whereas the other is the attributive possessive construction (' $\mathrm{X}$ 's $\mathrm{Y}$, the $\mathrm{Y}$ of $\mathrm{X}$ '). The former is a clause, whereas the latter is a phrase. It will be argued that both types of constructions may have emerged in the Uralic languages without the contribution of any foreign influence, but as far as the retention of the latter is concerned, foreign influence may have had a role in it in Uralic languages that were engaged in intensive Uralic-Turkic linguistic contacts.
\end{abstract}

Keywords: possessive, izafet, habitive, language contact, case marking

In the Uralic languages, two types of constructions serve as a clause-level expression of a possessive relationship:

(a) the possessed subject is in the nominative, while the nominal standing for the possessor has some case suffix that may be either grammatical (nominative, genitive, or dative) or else adverbial (lative, locative, or ablative); the possessed noun may or may not bear a personal possessive suffix, and the clause may or may not involve a copula; or

(b) the possessed noun is the direct object of a verb meaning 'have'.

* A preliminary version of this paper was presented at the Seventh International Congress of Hungarian Linguistics, Budapest, August 29-31, 2004. 
These main types comprise several subtypes. Neither of these types is exclusively used in the individual Uralic languages, although one of them is usually the dominant one. The habitives of certain Finno-Ugric languages have been claimed to be related to similar constructions occurring in Indo-European languages spoken in adjoining territories.

Phrase-level possessive relationship, on the other hand, is expressed by an attributive construction in which the possessive attribute is a nominal in some grammatical or adverbial case (nominative or genitive, respectively localis), while the possessed nominal may or may not have a possessive personal suffix. The subtype in which the possessor is not a personal pronoun and the possessed noun bears a personal suffix has been referred to by several researchers, on the basis of the name of a similar construction in Turkic languages, by the technical term "izafet". With respect to izafet constructions in some Uralic languages, some researchers suggested the possible influence of Turkic languages that are (or used to be) spoken in neighbouring areas.

1. One of the characteristic features of Uralic languages is that they tend not to make use of a verb meaning 'have', although such a verb is not completely unattested in them, either (it is rather generally used in Ob-Ugric).

1.1. The habitive construction most often attested in various Uralic languages is of the type exemplified by Latin mihi liber est 'I have a book' [lit. to-me book is]. That is, it involves the verb 'be', a nominal-mostly casemarked or followed by a postposition - standing for the possessor, and a possessed nominal that often has a possessive personal suffix attached to it. The individual languages may mark the possessor in diverse ways. In Finnic, Mordvin, Cheremis, and Samoyedic, reflexes of Proto-Uralic genitive ${ }^{*} n$ and/or dative ${ }^{*} n$ are normally used in habitive constructions; Hungarian started to use dative -nak/-nek (of a lative postpositional origin) for that purpose; Finnic languages - except for Kurland Livonianuse the allative, the adessive, or the ablative as a secondary device, while the locative is used in Lappish, the adessive or the ablative in Permic, and a locative postposition in Selkup. In the Finnic-Lappish group, the possessed noun never takes possessive personal suffixes, whereas in Hungarian it always does. In the rest of the languages, both solutions are used, with one of them dominant, at most. The verb is usually overt, but its position is not fixed across languages and across constructions. 
Thus, the scheme of the Uralic habitive construction is "Noun- $\varnothing /$ Gen/ Adv/Postp + Noun- $\varnothing /$ Px (+ 'is')".

The morphological shapes of habitive and attributive possessive constructions are interrelated as sown below in a tabular form:

\begin{tabular}{|c|c|c|}
\hline & $\begin{array}{l}\text { IN HABITIVE } \\
\text { CONSTRUCTIONS }\end{array}$ & $\begin{array}{l}\text { IN ATTRIBUTIVE } \\
\text { CONSTRUCTIONS }\end{array}$ \\
\hline Balto-Finnic & $\begin{array}{l}\text { case markers involving } l \text {, } \\
\text { genitive }\end{array}$ & genitive \\
\hline Lappish & static local cases & genitive \\
\hline Mordvin & genitive & genitive \\
\hline Cheremis & genitive & nominative, genitive \\
\hline Permic & $\begin{array}{l}\text { case markers involving } l \text {, } \\
\text { nominative }\end{array}$ & $\begin{array}{l}\text { case markers involving } l \text {, } \\
\text { nominative }\end{array}$ \\
\hline Ob-Ugric & $\begin{array}{l}\text { nominative, locative, } \\
\text { postposition }\end{array}$ & nominative, locative \\
\hline Hungarian & dative (> genitive) & $\begin{array}{l}\text { nominative, } \\
\text { dative ( }>\text { genitive) }\end{array}$ \\
\hline Northern Samoyedic & nominative, genitive & genitive \\
\hline Southern Samoyedic & $\begin{array}{l}\text { nominative, genitive, } \\
\text { postposition }\end{array}$ & genitive \\
\hline
\end{tabular}

Note: The dative and genitive interpretation of Hungarian -nak/-nek is not uncontroversial in the literature (cf. e.g., Korompay 1991, 301-2 vs. Kiefer 2000, 577-8).

In addition to a verbal predicate and the subject (that is, the possessed noun), habitive constructions usually involve the possessor, too. Whenever the possessed noun bears a possessive personal suffix - which is commonly the case outside Balto-Finnic and Lappish -, pronominal possessors are represented by personal suffixes, hence the possessive personal pronouns need not be overt in such cases. Overt possessors are in the genitive (going back to dative) in Finnic; also in Finnic as well as in Lappish it may be the case that the possessor is in the localis and the possessed noun has no personal suffix (within this group, Kurland Livonian and Southern Lappish are exceptions in that the possessor is suffixed by $-n$ in the former and by the genitive suffix in the latter); in Volgaic and Permic languages, the possessed noun does not necessarily have a personal suffix but then the possessor has to be case-marked; Ob-Ugric languages, lacking the genitive, use the nominative instead.

Examples: Finnish minu-n on nälkä- $\varnothing \sim$ minu-lla on nälkä- $\varnothing$ 'I am hungry', minu-lla on lapsi- $\varnothing$ 'I have a child', Livonian $\mathrm{K} i z \bar{a}-n$ um tidār- $\varnothing$ 
'the man has a daughter', Lappish $\mathrm{N}$ makkár beatnagat- $\varnothing$ du-s leat? 'what kind of dogs do you have?', mu-s dat gal leat buoret beatnagat- $\varnothing$ 'I do have good dogs', mu-st la manna- $\varnothing$ 'I have a child', Lappish S muw[gen] mana- $\varnothing$ 'I have a child', Mordvin eŕźa-ń uli suk-azo 'an Erzan has a dog',

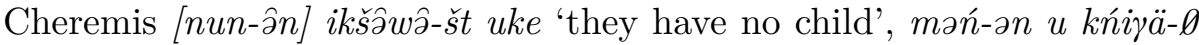
ulâ 'I have a new book', Votyak [men-am] nil-i vań 'I have a daughter', Zyryan joma-len pi-is abu 'the wizard has no sons' ni-len em kujim pi- $\varnothing$

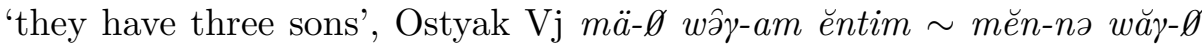

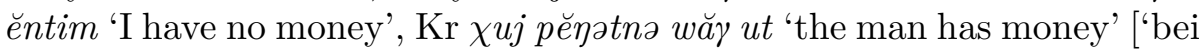

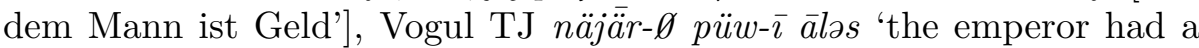

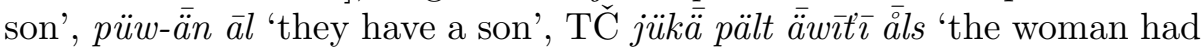
a daughter' ['bei der Frau war ihre Tochter'], Hungarian lov-am van 'I have a horse' [horse-my is], az apá-nak ház-a van 'the father has a house' [the father-dat house-his is] az apá-nak nincs ház-a 'the father has no house' [the father-dat is-not house-his].

1.2. The claim that the possessor-marking function of the dative is an ancient feature is supported by the fact that in several of the Uralic languages the dative suffix ${ }^{*} n$ is used in that role; note that constructions involving more recent dative suffixes are also attested. E.g., Cheremis

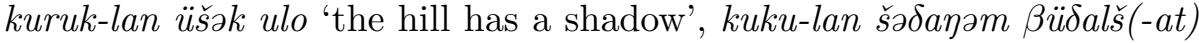
ulo 'the cuckoo has a wheat sower'. In Hungarian, the situation is similar: a hegy-nek árnyéka van 'the hill has a shadow', a kakukk-nak búzavetője van 'the cuckoo has a wheat sower'. The appropriateness of the dative to express a possessive relationship is also clearly demonstrated by the closest relatives of Hungarian: Ostyak and Vogul. In these languages, the dative of personal pronouns has a role in the expression of a possessive relationship if the possessed noun is in the singular - although not in habitive or attributive possessive constructions but in a predicative role (and perhaps also in that of a complement, as in the case of the Hungarian possessive pronouns enyém 'mine', tiéd 'yours', etc.):

(a) Ostyak N манәм ‘to me; my': тами ма шукем! —антә, манәм! 'Это моя крошка! - Нет, моя!'.

(b) Ostyak Kaz nayen 'to you; your', tuvel 'to him; his': tam tayki muj nayen muj tuvet 'эта белка или твоя, или его'.

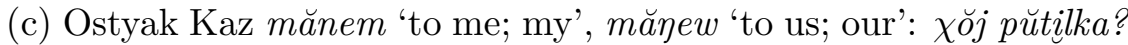
- mănem. - mănew. 'Whose bottle [is this]? - Mine. - Ours'.

(d) In Vogul, it is likewise the dative-lative forms of personal pronouns that figure as possessive pronouns, cf. N añzm 'me; to me; my', tawe 'him; to him; his', mènmèn 'us; to us; our (du. 1)', mānaw 'us; to 
us; our (pl. 1)': nēpək ānəm 'бумага моя', pisal' tawe 'ружье его', koləy mēnmēn 'дома (дв.) наши (дв.)', sālit mānaw 'олени наши'. This construction is also illustrated by the following Southern Vogul exam-

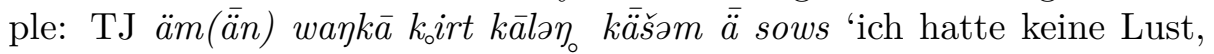
in dem Brunnen zu sterben', 'mir kam [eigtl. wurde] nicht meine Lust... zu sterben'. The sentence can be interpreted in two ways, depending on whether it includes a nominative or a dative pronoun: 'I had no desire to...' and 'there was no desire in me to...'.

1.3. As the foregoing suggest, in habitive constructions of present-day Uralic languages, the possessor often bears a case suffix (originally localis), not infrequently that of the dative; dative and lative are also known in that role in some Indo-European languages, among others (similarly with respect to attributive possessive constructions). The Indo-European languages, or their proto-languages, originally lacked a verb for 'have'; rather, they formed their habitive constructions with the dative of the possessor noun and the verb for 'be' (see Gamkrelidze-Ivanov 1984, 2889, and references therein). In Latin, if the possessed noun is emphasised, the verb is some finite form of 'be' and the possessor is in the dative (dativus possessivus), e.g., mihi liber est 'I have a book'; but if the possessor is made prominent, the genitive (genitivus possessivus) is used: patris est domus 'the house belongs to the father'. According to Havers (1911, 319 and footnote), this is "dativus sympatheticus" that occurs both in habitive and in attributive possessive constructions in some Indo-European languages; in Sanskrit and Old Greek, it is restricted to pronouns, especially personal pronouns, but in Vulgar Latin, in Germanic, and in Balto-Slavic, it was extended to nouns, and in Romanian, Albanian, Bulgarian, and Modern Greek, the genitive and the dative became syncretised (as in the Finnic and Volgaic groups of Uralic languages). E.g., German dialectal er ist ein Vetter zu mir, wem sein Hut 'wessen Hut', German dem Vater sein Sohn des Vaters sein Sohn, Dutch de vader zijn zoon 'id.', English server to his master, Old English him on pet heafod 'to-him on the head (= on his head)', French ce livre est à moi, le cheval à mon père, Italian descriver fondo a tutto l'universo 'to describe the essence of the whole world', Russian ему шесть лет, доктор ему осмотрел горло, Latvian kas tev ir? 'who/what do you have?'. Thus, the dativus possessivus found in Finno-Ugric languages is not unprecedented.

1.4. With respect to the origin of habitive and attributive possessive constructions involving dative or locative prepositional/postpositional 
phrases, radically diverse views have been expressed in terms of FinnoUgric-Indo-European contacts, listed here without comment:

(a) In the background of the Latvian and Russian constructions, some people claim there must be a Finno-Ugric substratum or adstratum, whereas others deny this; indeed, the question arose of whether the Finnic construction (Finnish minulla on...) is not of Russian origin to begin with.

(b) With respect to the function of the Livonian dative, perhaps some Latvian influence could be considered.

(c) Given that, in Ostyak, the locative of personal pronouns can be used to express the possessor, this probably shows the influence of Russian.

(d) A similar view has been expressed with respect to the Vogul postpositional construction.

(e) The Selkup postpositional phrase may be due to Russian influence, too; in this case, Selkup may have extended the earlier construction 'my reindeer is' by an item corresponding to Russian у меня but retained the possessive suffix as well.

(f) According to Nikolaeva (2002, 283-4), Hungarian dativus possessivus is the result of convergence with what she calls "European" languages; but in the same paper, she also claims that Hungarian "copied" that construction from neighbouring languages.

As far as I know, the origin of Hungarian dativus possessivus has been satisfactorily explained by historical linguists and, mutatis mutandis, this applies to events that may have taken place in long-bygone periods. Therefore, no obscure links are to be suspected with respect to the origin of the corresponding Uralic and Indo-European constructions.

The nominal bearing a locative suffix or a locative postposition may originally have served to express the whereabouts of the denotatum of the possessed noun rather than the identity of the possessor, as can still be felt e.g., in Finnish meillä on vieraita 'we have guests' 'there are guests in our place'; this suggests that such constructions may have arisen in a natural, spontaneous manner.

2. Turning to izafet constructions, I have to explain very briefly what that term is meant to express since the notion is not widely known, as far as I am aware (cf. Yartseva 1990, 172). Given that the term is used for Uralic languages with reference to patterns in Turkic languages, I considered primarily definitions that interpret it in the framework of discussions of 
Turkic languages. The scanty Turkological literature on the issue that I had access to, as well as references within Uralistics, suggest that an attributive possessive construction counts as an instance of izafet if the possessive relationship is marked (at least) on the possessed noun, and its marker is a possessive personal suffix, e.g., Hungarian a ház tete-je [the house roof-its], a ház-nak a tete-je [the house-dat the roof-its] 'the roof of the house'. Hence, izafet is one of the possessive constructions, of which Uralic languages exhibit at least four. These are as follows:

(a) The possessive relationship is not morphologically marked on either part of the construction (this, then, is not izafet); often, compounds and compound-like phrases belong here, e.g., Hungarian házteto" 'roof of house' [lit. house-roof]; Mordvin utom keøkš 'дверь амбара (букв.: амбар-дверь)'; Cheremis pünз̆ö wијə-što 'on top of the hill'; Votyak škola sad 'школьный сад'; Zyryan pizan dera 'скатерть; сальфетка'; Ostyak Vj ni potinka 'the woman's shoes'; Vogul punk-sow 'scalp'; Selkup pōt pīry 'высота дерева', that is: "Noun- $\varnothing+$ Noun- $\emptyset$ ".

(b) A possessive morpheme only occurs on the attributive constituent (this is not izafet either, since the head noun does not exhibit any mark of possessivity), e.g., Finnish talo-n katto 'roof of the house'; Cheremis

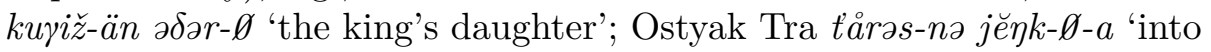
(the water of) the sea'; Yurak-Samoyed pa- ${ }^{2}$ hade?-Ø 'смола дерева';

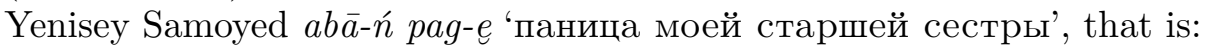
"Noun-Cx + Noun- $\varnothing "$.

(c) The possessive relationship is only marked on the possessed noun, by a possessive personal suffix (this is izafet, since the morpheme expressing the relationship between the constituents is located on the head noun), e.g., Hungarian a ház- $\varnothing$ tete-je 'roof of the house'; Ostyak Vj rät- $\varnothing$

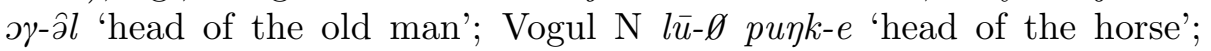
Zyryan kate- $\varnothing$ źugj-as 'in Kätchens Schlinge', that is: "Noun- $\varnothing+$ NounPx".

(d) Both the attribute and the head noun exhibit morphemes expressing the possessive relationship (this is also izafet, since one of the morphemes expressing the relationship between the constituents is located on the head noun), e.g., Hungarian a ház-nak a tete-je 'the roof

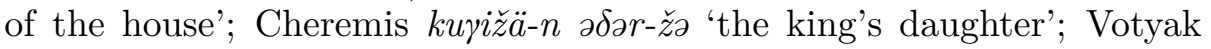

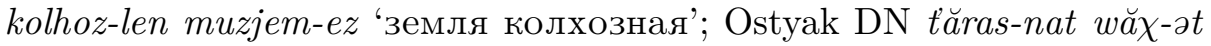
'das Geld des Kaufmannes'; Yurak-Samoyed ńa-kan meti-da 'упряжные олени моего старшего брата (букв. брата-моего упряжные-его)'; Yenisey Samoyed $k \varepsilon \delta \varepsilon r-'$ koba- $\delta a$ 'шкура дикого оленя', that is: "Noun$\mathrm{Cx}+$ Noun-Px". 
2.1. Bereczki (1983a, 65; 1984, 308), the author who has discussed the matter the most thoroughly, mentions Volgaic and Permic languages, as well as Hungarian, as languages that employ izafet constructions, noting that - except for Hungarian - these languages also exhibit the original Finno-Ugric construction involving no possessive personal suffixes. Simonyi $(1914,139)$ was furthermore aware that the same construction occurred in Vogul and in Ostyak, too. Thereby the insight of Beke (1914$1915,21)$ the author who first investigated this issue, saying that izafet is known to exist (albeit not exclusively) in all Finno-Ugric languages except for Finnic and Lappish, appears to have proved correct.

2.2. For curiosity's sake let me add here that (of the Indo-European languages spoken in Europe) possessive phrases reminiscent of izafet constructions of Uralic and Altaic languages are not totally unfamiliar in Germanic and in Romance, either. The literature I have looked at knows of only two such groups of Indo-European languages, e.g., German wem sein Hut 'wessen Hut', dem Vater sein Haus des Vaters sein Haus $\sim$ Dutch de vader zijn huis, Italian della mia sopravvesta il suo colore 'the colour of my coat'. In Germanic, the phrase-initial possessor is topicalised (Ramat 1986, 587), and the possessor is (at least historically speaking) in the dative, whereas in Italian the genitive form (della) is used; the possessed noun is determined by a third-person possessive attributive pronoun in all three languages cited. That is, these phrases exactly match the izafet constructions of Uralic languages, with the difference that they refer back to the possessor by a possessive pronoun rather than by a possessive personal suffix.

2.3. The emergence of the izafet construction does not have a large literature but it includes at least three different views. Some authors claim that it is probably of Proto-Uralic origin (Hajdú 1987, 222-3, cf. Benkö 1979, 57; 1988, 24-5), others trace it back to contacts with Turkic languages, at least with respect to Volgaic and Permic languages, and Hungarian (Beke 1914-1915, 21-7; Bereczki 1983b, 214; Rédei 1980, 86), whereas Fokos $(1939,16)$ considers it to be a result of internal development. With respect to Samoyedic, I am unaware of attempted explanations of origin.

Ugric languages may have introduced the izafet construction due to the fact that the genitive they had inherited from Proto-Finno-Ugric had been lost and in some cases they needed to reflect the grammatical relationship in their possessive constructions, or to make the possessor more prominent by topicalising it, but it was not possible to unambigu- 
ously indicate by a case marker, due to lack of genitive, that two nouns formed a possessive construction. In such cases, Ugric languages could (and can) disambiguate the syntactic relationship between the two constituents by a third-person possessive suffix attached to the possessed noun, topicalising the possessor; the use of the person marker was generalised in Hungarian e.g., (a) fiú láb-a 'the foot of the boy', whereas in Ob-Ugric it remained an occasional topicalising device. This may have been reinforced by the analogy of constructions involving a pronominal possessor; as Fokos (ibid.) pointed out, "constructions like apám háza 'my father's house' may have been modelled after constructions like ő háza 'his house'." Beke (1914-1915, 21-7) explained the emergence of izafet constructions in these Finno-Ugric (Volgaic, Permic, Ugric) languages by an influence of Volga Turkic languages, and Bereczki (1983a, 65) did the same with respect to Permic and Volgaic languages, whereas for Hungarian he thought it was possible that "it was a result of internal development." The possessive personal suffix also emerged as an alternative in Permic and Volgaic languages. Given that its overt occurrence is obligatory in Hungarian, we can say that this language is more consistent in this kind of possessor marking than Turkic languages are. That is, Hungarian is the ideal izafet language. Another point in favour of the spontaneous development account is that not all Uralic languages have been spoken next to Turkic languages for a thousand years or so (in the case of Hungarian, such coexistence was but a moment's episode, in a historical perspective). I think, in accordance with Fokos, Hajdú, and Benkő, that the emergence and/or retention of izafetism was underpinned by internal necessity.

An argument supporting the Turkic origin of izafet constructions in some Finno-Ugric languages is that they are unknown in Finnic and Lappish that were not in contact with Turkic languages. Thus, provided I do not accept the alleged role of Turkic influence in this respect, I have to find an answer to the question of why this construction is not attested in the westernmost languages of the family. In Finnic or Lappish, topicalisation of this kind did not occur, although it undoubtedly might have, rather - at least in Finnish - it was the possessor with a genitive suffix that acquired additional prominence. This can be explained, I think, by the fact that the genitive suffix had been retained, a necessary but not sufficient condition for izafet constructions not to occur in languages of the westernmost group. That construction is not quite generally used in other Uralic languages, either, with the sole exception of Hungarian. But 
then, this is the single Uralic language that had the shortest contact of all with Turkic languages. Whether the izafet construction is of a ProtoUralic origin or it emerged in the separate lives of individual languages or language groups, I would be reluctant to claim that its emergence in just these languages is due to mere chance. Indeed, intensive contacts with Turkic languages may have stimulated either the retention of original izafet constructions or the reinforcement of a trend of development triggered by an internal need. Thus, I do not deny the possible role of Uralic-Turkic contacts or bilingualism, yet I do not at all see it as a decisive factor. In that respect, it is also worth noting that izafet(-like) constructions can be found in European Indo-European languages that had no Turkic contacts whatsoever. In sum: the izafet construction of Uralic languages may be a result of internal changes, rather than that of an adopted foreign model.

3. Both habitive and izafet constructions may have emerged in the Uralic languages without the contribution of any foreign influence, but as far as the retention of izafet is concerned, foreign influence may have had a role in it in Uralic languages that were engaged in intensive Uralic-Turkic linguistic contacts.

\section{References}

Beke, Ödön 1914-1915. Türkische Einflüsse in der Syntax finnisch-ugrischer Sprachen. In: Keleti Szemle $15: 1-77$.

Benkő, Loránd 1979. Über die Bezeichnung des ungarischen Possessivattributs. In: Christoph Gläser - János Pusztay (eds): Festschrift für Wolfgang Schlachter zum 70. Geburtstag. Veröffentlichungen der Societas Uralo-Altaica. Band 12, 57-64. Otto Harrassowitz, Wiesbaden.

Benkő, Loránd 1988. A magyar birtokos jelzős szerkezet jelölésének történetéből [From the history of Hungarian attributive possessive constructions]. In: Magyar Nyelv $84: 24-31$.

Bereczki, Gábor 1983a. A török nyelvek hatása a magyarra [The influence of Turkic languages on Hungarian]. In: Mémoires de la Société Finno-ougrienne 185 : 59-72.

Bereczki, Gábor 1983b. A Volga-Káma-vidék nyelveinek areális kapcsolatai [Areal contacts of languages of the Volga-Kama region]. In: János Balázs (ed.): Areális nyelvészeti tanulmányok [Studies in areal linguistics], 207-36. Tankönyvkiadó, Budapest.

Bereczki, Gábor 1984. Die Beziehungen zwischen den finnougrischen und türkischen Sprachen im Wolga-Kama-Gebiet. In: Nyelvtudományi Közlemények 86 : 307-14.

Acta Linguistica Hungarica 53, 2006 
Fokos, Dávid 1939. Finnugor-török mondattani egyezések [Finno-Ugric-Turkic syntactic correspondences]. In: Magyar Nyelvőr 68:13-9.

Gamkrelidze, T. V.- V. V. Ivanov [Гамкрелидзе, Т. В.-В. В. Иванов] 1984. Индоевропейскй язык и индоевропейцы. Реконструкция и историко-типологический анализ праязыка и протокультуры. Издательство Тбилисского университета, Тбилиси.

Hajdú, Péter 1987. Die uralischen Sprachen. In: Péter Hajdú-Péter Domokos: Die uralischen Sprachen und Literaturen, 21-450. Budapest \& Hamburg, Akadémiai Kiadó \& Helmut Buske Verlag.

Havers, Wilhelm 1911. Untersuchungen zur Kasussyntax der indogermanischen Sprachen. Untersuchungen zur indogermanischen Sprach- und Kulturwissenschaft 3. Verlag Karl J. Trüber, Straßburg.

Kiefer, Ferenc 2000. A ragozás [Inflection]. In: Ferenc Kiefer (ed.): Strukturális magyar nyelvtan 3. Morfológia [A structural grammar of Hungarian, Vol. 3: Morphology], 569-618. Akadémiai Kiadó, Budapest.

Korompay, Klára 1991. A névszóragozás [Declension]. In: Loránd Benkő-Erzsébet E. Abaffy-Endre Rácz (eds): A magyar nyelv történeti nyelvtana. 1. kötet: A korai ómagyar kor és előzményei [A historical grammar of Hungarian. Volume 1: Early Old Hungarian and its antecedents], 284-318. Akadémiai Kiadó, Budapest.

Nikolaeva, Irina 2002. The Hungarian external possessor in a European perspective. In: Rogier Blokland-Cornelius Hasselblatt (eds): Finno-Ugrians and Indo-Europeans: Linguistic and literary contacts (Studia Fenno-Ugrica Groningana 2), 272285. Shaker Publishing, Maastricht.

Ramat, Paolo 1986. The Germanic possessive type dem Vater sein Haus. In: Dieter Kastovsky-Aleksander Szwedek (eds): Linguistics across historical and geographical boundaries. In honour of Jacek Fisiak on the occasion of his fiftieth birthday. Volume 1. Linguistic theory and historical linguistics. Trends in linguistics. (Studies and Monographs 32), 579-90. Mouton de Gruyter, Berlin \& New York.

Rédei, Károly 1980. [Diskussionsbeitrag]. In: Gyula Ortutay (ed.): Congressus Quartus Internationalis Fenno-Ugristarum Budapestini habitus anno 1975. Pars II, 85-7. Akadémiai Kiadó, Budapest.

Simonyi, Zsigmond 1914. A jelzők mondattana [The syntax of attributes]. Magyar Tudományos Akadémia, Budapest.

Yartseva, V. N. (еd.) [Ярцева, В. Н. (отв. ред.)] 1990. Лингвистический энциклопедический словарь. Советская энциклопедия, Москва. 